Article

\title{
Investigating the Effect of Mono- and Dimeric 360A G-Quadruplex Ligands on Telomere Stability by Single Telomere Length Analysis (STELA)
}

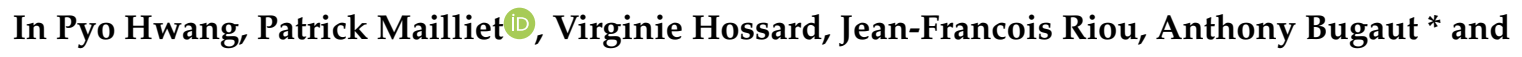 \\ Lauréline Roger* \\ “Structure and Instability of Genomes" Laboratory, Muséum National d'Histoire Naturelle (MNHN), \\ Inserm U1154, CNRS UMR 7196, 43 rue Cuvier, 75005 Paris, France; in-pyo.hwang@etu.parisdescartes.fr (I.P.H.); \\ patrick.mailliet@mnhn.fr (P.M.); virginie.hossard@mnhn.fr (V.H.); riou@mnhn.fr (J.-F.R.) \\ * Correspondence: abugaut@mnhn.fr (A.B.); lroger@mnhn.fr (L.R.)
}

\begin{abstract}
Academic Editor: Danzhou Yang
Received: 30 November 2018; Accepted: 31 January 2019; Published: 6 February 2019

check for updates

Abstract: Telomeres are nucleoprotein structures that cap and protect the natural ends of chromosomes. Telomeric DNA G-rich strands can form G-quadruplex (or G4) structures. Ligands that bind to and stabilize G4 structures can lead to telomere dysfunctions by displacing shelterin proteins and/or by interfering with the replication of telomeres. We previously reported that two pyridine dicarboxamide G4 ligands, $360 \mathrm{~A}$ and its dimeric analogue $(360 \mathrm{~A})_{2 \mathrm{~A}}$, were able to displace in vitro hRPA (a single-stranded DNA-binding protein of the replication machinery) from telomeric DNA by stabilizing the G4 structures. In this paper, we perform for the first time single telomere length analysis (STELA) to investigate the effect of G4 ligands on telomere length and stability. We used the unique ability of STELA to reveal the full spectrum of telomere lengths at a chromosome terminus in cancer cells treated with $360 \mathrm{~A}$ and $(360 \mathrm{~A})_{2 \mathrm{~A}}$. Upon treatment with these ligands, we readily detected an increase of ultrashort telomeres, whose lengths are significantly shorter than the mean telomere length, and that could not have been detected by other methods.
\end{abstract}

Keywords: G-quadruplex structures; G-quadruplex ligands; telomere; STELA

\section{Introduction}

Telomeres are nucleoprotein structures that cap and protect the natural ends of chromosomes by preventing them from being recognized as DNA double strand breaks [1]. In human cells, telomeric DNA is composed of the TTAGGG sequence tandemly repeated to a size up to $25 \mathrm{~kb}$. Their functions rely on a complex of telomere-associated-proteins named "shelterin" [2]. In most somatic cells, telomeres erode at each cell division due to the so-called "end-replication problem" [3,4]. But they can also shorten as a consequence of stochastic deletion events, resulting in telomeres extremely shorter than the bulk population, often called TDEs (for telomere deletion events) [5-8]. The underlying mechanisms that result in these TDEs are still unclear. Telomere erosion ultimately results in a partial loss of telomere function, triggering a stable cell cycle arrest termed replicative senescence. In the absence of fully functional DNA damage checkpoints, telomeres can shorten to a length at which they become dysfunctional and capable of fusion with other telomeres or with non-telomeric loci, which may contribute to the acquisition of large-scale genomic rearrangements and cancer progression.

Human telomeric G-rich sequences can form G-quadruplex (or G4) structures in vitro [9]. One of the first indications that G4 structures may be present at human telomeres came from the observation that a tritiated derivative of the selective G-quadruplex ligand 360A preferentially bound to the ends of metaphase chromosomes [10]. More recently, G4 structures at telomeres in human cells have also been 
visualized using an engineered structure-specific antibody [11]. Furthermore, a number of helicases, which have been shown to unwind G4 structures in vitro, localize to telomeres and are required to maintain telomere integrity [12,13]. G4 structures have also been mapped in other regions of the genome and it has been suggested that G4s may be involved in gene regulation [11,14,15].

Over the past decades, numerous small molecules have been synthesized that bind to and stabilize human telomeric G4 structures in vitro, mainly with the view to developing potential anticancer agents [16-18]. Some of these ligands were shown to generate telomere dysfunction in cancer cell lines, such as telomere fusion, telomere doublets, and/or telomere complete loss [19-21]. These telomere aberrations can result from telomere uncapping and from interference with telomere replication [22-25].

Recently, we reported on the in vitro binding properties of the pyridine dicarboxamide G4 ligand $360 \mathrm{~A}$ and its newly synthesized dimeric analogue (360A) $)_{2 \mathrm{~A}}$ to telomere-mimicking oligonucleotides forming up to four contiguous G4 structures [26]. This study revealed that both molecules stabilize telomeric higher-order G4 structures and that they were able to displace human replication protein A (hRPA) from telomeric DNA, with a greater efficiency for the dimeric ligand than the monomer form.

Here, we investigate the cellular effect of $360 \mathrm{~A}$ and $(360 \mathrm{~A})_{2 \mathrm{~A}}$ on telomere length by undertaking single telomere length analysis (STELA). Developed by Baird et al., STELA is a PCR-based technology that gives the full spectrum of telomere lengths at a single chromosome terminus in dividing and non-dividing cells [5]. A modified version of STELA was used to identify the end nucleotide of the telomeric C-strand [27]. In one case, this STELA-based approach was used to study the effect of a bromide derivative of 360A (360A-Br) on the C-strand terminal sequence of XpYp telomere in the HT1080 fibrosarcoma cell line, which demonstrated a minor effect in the nucleotide composition [28]. However, STELA was never used to study the impact of G4 ligands on telomere length. Of particular importance for this study is the unique ability of STELA to detect ultrashort dysfunctional telomeres that cannot be visualized by other hybridization-based methods, such as telomere restriction fragment (TRF) and telomere Q-FISH. We showed that STELA is a method of choice to readily detect TDEs and that the frequency of these events tends to increase when G4 structures at telomeres are stabilized by $360 \mathrm{~A}$ and $(360 \mathrm{~A})_{2 \mathrm{~A}}$. This work represents the first example of the use of STELA to study the effect of G4 ligands on telomere length.

\section{Results}

\section{1. $360 A$ and $(360 A)_{2 A}$ Inhibit the Proliferation of A549 Cells with No Effect on Mean Telomere Length}

First, we evaluated the effect of $360 \mathrm{~A}$ and its dimer form $(360 \mathrm{~A})_{2 \mathrm{~A}}$ (Figure 1a) on the cell growth of A549 lung carcinoma cell lines, a model cell line that was previously used to show the preferential binding of $360 \mathrm{~A}$ to telomeres [10]. Cells were treated with $5 \mu \mathrm{M}$ of $360 \mathrm{~A}$ or $(360 \mathrm{~A})_{2 \mathrm{~A}}$ and cumulative population doublings (PDs) were calculated at each reseeding until complete growth arrest, at which point the cultures were terminated. From three independent experiments, we observed that treatment with $5 \mu \mathrm{M}$ of 360A led to an inhibition of cell proliferation within 11 days of treatment, as previously shown in other cancer cell lines (Figure 1b) [19-21]. Treatment with the newly synthesized dimer $(360 \mathrm{~A})_{2 \mathrm{~A}}$ led to a comparable antiproliferative effect (Figure 1b). 
(a)

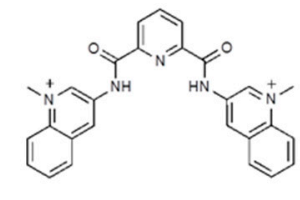

$360 \mathrm{~A}$

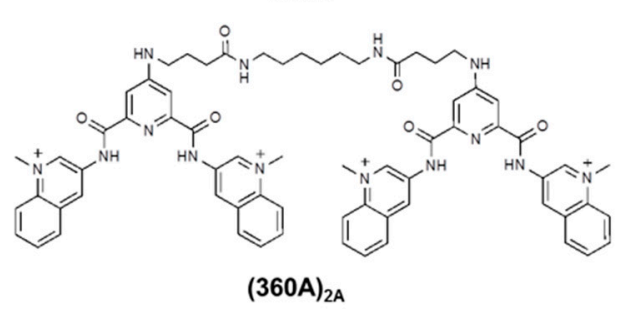

(b)

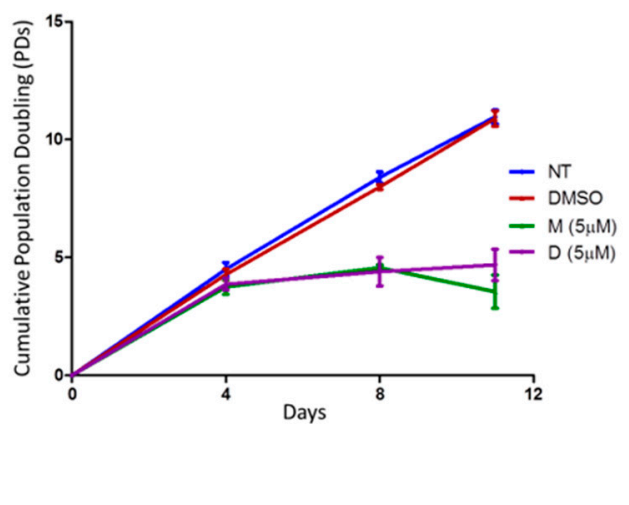

Figure 1. Chemical structure of $360 \mathrm{~A}$ and $(360 \mathrm{~A})_{2 \mathrm{~A}}$ and the effect of these ligands on the proliferation of A549 cells: (a) Chemical structure of G4 ligands 360A and (360A) 2A; (b) Cell growth curves plotting mean PDs and days in culture of non-treated A549 (NT), A549 treated with 0.1\% DMSO (DMSO), with $5 \mu \mathrm{M}$ of $360 \mathrm{~A}(\mathrm{M})$, or with $5 \mu \mathrm{M}$ of $(360 \mathrm{~A})_{2 \mathrm{~A}}$ (D) ( $=3$ independent experiments; error bars, SD).

Next, we used the genomic DNA extracted from samples obtained at each reseeding of the cell growth experiments to examine the effect of $360 \mathrm{~A}$ and $(360 \mathrm{~A})_{2 \mathrm{~A}}$ on $17 \mathrm{p}$ (i.e., the short arm of chromosome 17) telomere length using STELA [5]. A prerequisite to STELA is the identification of a chromosome-specific telomere-adjacent DNA sequence. As the subtelomere sequence of human 17p is well characterized, STELA at 17p telomere is robust and has been extensively used [6-8]. STELA is a PCR-based approach that relies on the use of a set of primers comprising: (i) a linker primer, called "telorette", constituted by seven bases complementary to the G-rich $3^{\prime}$ overhang followed by a unique 20-nucleotide tail non complementary to the telomere; (ii) a subtelomere specific primer close to the beginning of the telomere and specific to a chromosome end; and (iii) a primer called "teltail", whose sequence is identical to the telorette 20-nucleotide tail (Figure 2a). Each extracted DNA sample is analyzed with typically six PCR reactions that contain between four and 30 amplifiable molecules. PCR products are then resolved on an agarose gel and detected by southern blot hybridization with a radiolabeled telomere probe. Each band detected on the membrane represents a single telomere. Thus, STELA gives the full spectrum of telomere lengths of a specific chromosome end and can detect rare short telomeres (TDEs), distinct from the bulk population, which cannot be visualized by any other methods. We performed STELA to measure 17p telomere length at each reseeding point (i.e., at day 4, 8, and 11), during the course of the cell growth experiments, in control and treated cells. Overall, we did not observe any significant difference in the mean telomere length of cells treated with $360 \mathrm{~A}$ and $(360 \mathrm{~A})_{2 \mathrm{~A}}$ compared with control cells (non-treated or $0.1 \% \mathrm{DMSO}$ ) as a function of PDs (Figure $2 b$ ). These data are consistent with previous observations in other cancer cell lines showing that the antiproliferative effect of 2,6-pyrimide-dicarboxamide derivatives was not associated with progressive telomere shortening with ongoing cell divisions [19,21].

However, the unique ability of STELA to detect TDEs allowed us to observe rare telomeres that were significantly shorter $(\leq 2.2 \mathrm{~kb})$ than the bulk telomere length distributions (black arrow heads in Figure 2b). We noticed that these TDEs seemed more frequent in G4 ligand-treated cells than in control cells. 
(a)

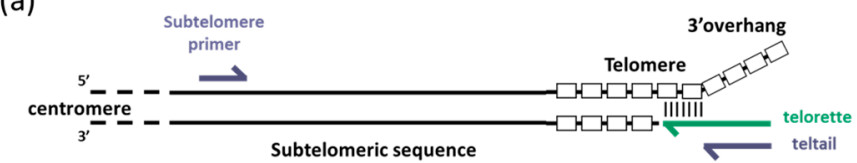

(b)

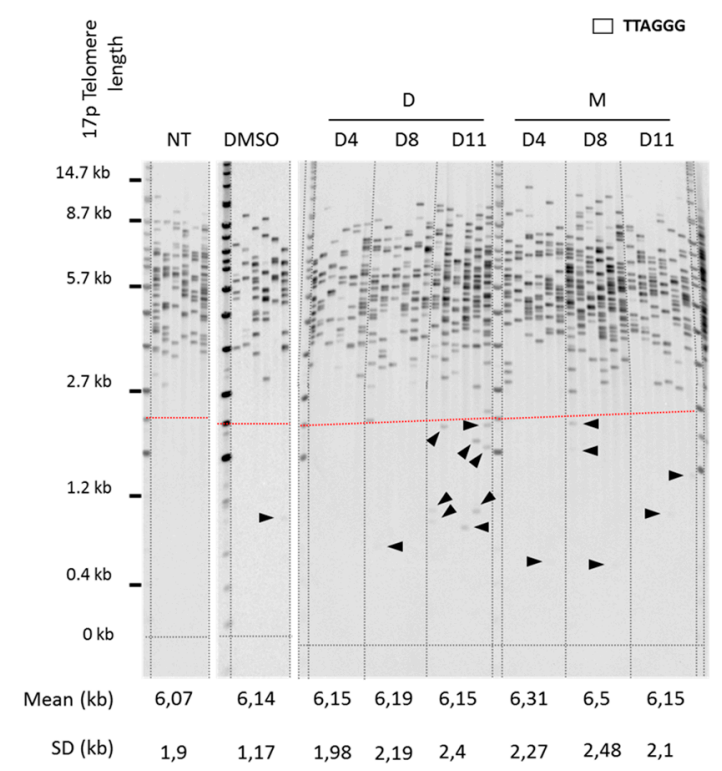

Figure 2. Treatment with $360 \mathrm{~A}$ and $(360 \mathrm{~A})_{2 \mathrm{~A}}$ had no effect on mean telomere length: (a) Schematic representation of the principle of STELA [5]; (b) STELA at 17p telomere in non-treated A549 (NT), A549 treated with $0.1 \%$ DMSO (DMSO), $5 \mu \mathrm{M} 360 \mathrm{~A}(\mathrm{M})$, or $5 \mu \mathrm{M}(360 \mathrm{~A})_{2 \mathrm{~A}}$ (D) after 4, 8, and 11 days of treatment (D4, D8, D11) (representative STELA from experiment (1)). Each lane represents a PCR and each band a telomere. The mean and SD of the telomere length are shown below. Arrows show examples of telomere deletion events (TDEs) (i.e., telomeres shorter than $2.2 \mathrm{~kb}$ (red dashed line)).

\section{2. $360 \mathrm{~A}$ and $(360 \mathrm{~A})_{2 \mathrm{~A}}$ Induce Telomere Deletion Events in A549 Cells}

In order to accurately measure the frequency of the TDEs, we next scaled up our analysis by increasing to at least 18 the number of STELA PCRs per sample (Figure 3a). The last PD points (i.e., when the cells stopped proliferating and when the cultures were terminated) of the treated cells were compared to the controls in two independent experiments. From 315 to 631 telomeres were analyzed per sample (Figure $3 b)$. Non-treated and $0.1 \%$ DMSO cells displayed a low frequency of TDEs $(0.90 \%$ and $1.27 \%$, respectively), which was comparable to what has been previously observed at $17 \mathrm{p}$ telomeres in normal cells [7]. Interestingly, TDEs increased to $2.34 \%$ and $2.69 \%$ in cells treated with the G4 ligand $360 \mathrm{~A}$ in experiment 1 and 2, respectively. Even if we observed a reproducible trend toward an increased frequency of TDEs, the differences between treated vs non-treated or $0.1 \%$ DMSO control cells were not statistically significant, probably due to the low frequency of TDEs. For the dimeric ligand $(360 \mathrm{~A})_{2 \mathrm{~A}}$, TDEs increased to $3.57 \%$ and $3.33 \%$ in experiment 1 and 2, respectively. This represents a 3.9 -fold (experiment 1 , chi-square test, $p=0.016$ ) and 3.7-fold (experiment 2, chi-square test, $p=0.02$ ) increase when compared to non-treated cells, and a 2.8-fold (experiment 1 , chi-square test, $p=0.046$ ) and 2.6-fold increase (experiment 2 , chi-square test, $p=0.066$ ) when compared to $0.1 \%$ DMSO control. Such results clearly indicate that the ligand $(360 \mathrm{~A})_{2 \mathrm{~A}}$ affects telomere stability. 
(a)

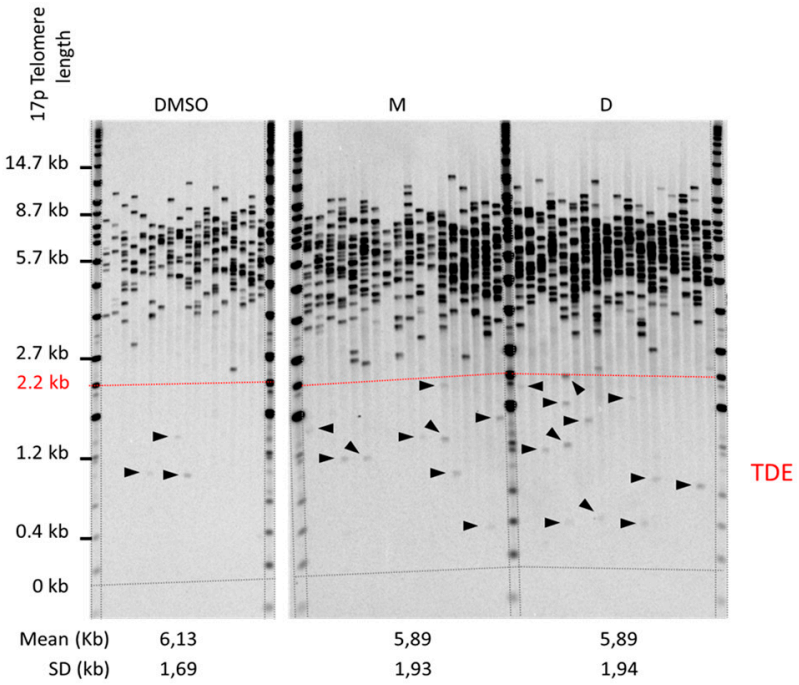

(b)

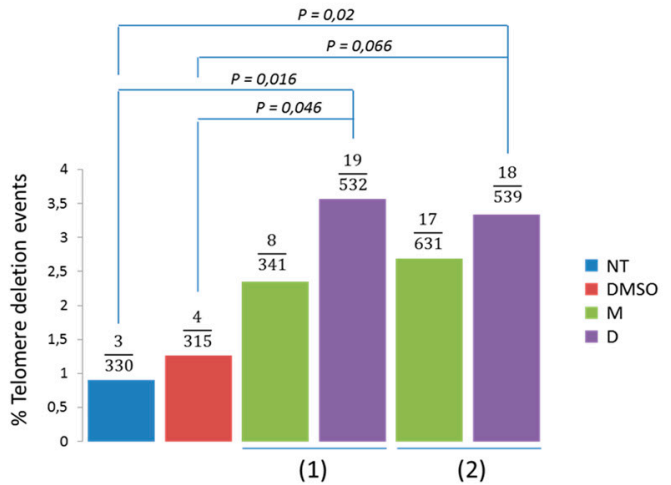

Figure 3. $360 \mathrm{~A}$ and $(360 \mathrm{~A})_{2 \mathrm{~A}}$ induced telomere deletion events in A549 cells: (a) Representative experiment (from experiment (2)) of the scaled up STELA at 17p telomere in the last PD points of A549 treated with $5 \mu \mathrm{M}$ of $360 \mathrm{~A}(\mathrm{M})$ or $5 \mu \mathrm{M}$ of $(360 \mathrm{~A})_{2 \mathrm{~A}}$ (D). Each lane represents a PCR and each band a telomere; (b) Histograms showing the proportion of TDEs in 2 independent experiments in the last PD points (i.e., at day 11 for both $360 \mathrm{~A}$ and $(360 \mathrm{~A})_{2 \mathrm{~A}}$ in experiment 1 ; and at day 11 and 8 for $360 \mathrm{~A}$ and $(360 \mathrm{~A})_{2 \mathrm{~A}}$, respectively, in experiment 2 ) of $\mathrm{A} 549$ treated with $5 \mu \mathrm{M}$ of $360 \mathrm{~A}(\mathrm{M})$ or $5 \mu \mathrm{M}$ of $(360 \mathrm{~A})_{2 \mathrm{~A}}$ (D). The Chi-square test was used to determine the $\mathrm{p}$ values.

\section{Discussion}

Using hybridization-based methods such as Q-FISH and TRF, many studies have showed that G4 ligands could lead to telomere shortening and complete loss. Q-FISH can inform on the telomere length of individual chromosome arms within the same cell and detect "signal free ends" called telomere loss. However, the resolution of this approach for the detection of extremely short telomeres is limited in comparison to STELA. Moreover, Q-FISH is restricted to the analysis of cells that are proliferating [29]. TRF gives the mean telomere length of all chromosomes and is biased toward the detection of longer telomeres [29].

Here, we used the unique ability of STELA to investigate, for the first time, the full spectrum of telomere lengths at a given chromosome terminus upon treatment with G4 ligands. Two pyridine dicarboxamide ligands were used: $360 \mathrm{~A}$ and its recently reported dimer form $(360 \mathrm{~A})_{2 \mathrm{~A}}$. Our results indicate that these ligands can induce rare events of extreme telomere shortening, manifested by an increase of TDEs whose lengths are significantly shorter than the mean telomere length.

TDEs have previously been detected in telomerase negative and positive cells and in normal and cancer cells. Yet, the underlying mechanisms of TDEs in human cells are still unclear. G4s represent a barrier for the progression of replication forks, potentially leading to fork stalling or fork collapse 
and replication-associated DNA double strand breaks (DSBs) [13]. Many helicases are able to resolve G4 structures in vitro [30]. It has been proposed that WRN helicase is required for the replication of the G-rich telomeric strand by resolving G4s at telomeres, thus allowing the replication fork to progress [31]. Human cells lacking WRN helicase display a complete loss of telomere, specifically at the G-rich strand. So, ligand-stabilized G4s that are unresolved at telomeres could be a potential mechanism that leads to TDEs.

In our study, the frequency of TDEs appeared slightly higher in cells treated with $(360 \mathrm{~A})_{2 \mathrm{~A}}$ compared to cells treated with 360A. This is interesting in regard to our previous in vitro data showing that $(360 \mathrm{~A})_{2 \mathrm{~A}}$ displaced hRPA from telomeric G-rich DNA with a greater efficiency than 360A [26]. hRPA is a single-stranded DNA-binding protein, which is involved in DNA replication [32], and it has been shown that hRPA associates with telomeres during replication [33,34]. Interestingly, expression of a mutant RPA in HT1080 has been shown to cause telomere shortening [35]. Consequently, a greater ability of $(360 \mathrm{~A})_{2 \mathrm{~A}}$ to displace hRPA could account for the differences in TDEs frequencies between cells treated with $(360 \mathrm{~A})_{2 \mathrm{~A}}$ and $360 \mathrm{~A}$.

To follow, it would be interesting to extend this study to other telomeres in order to assess if the impact of our G4 ligands on telomere stability is the same across all chromosome ends. Moreover, the mechanisms underlying TDEs upon treatment with G4 ligands still need to be clarified. It would be of particular interest to investigate the displacement of other proteins that are essential for telomere stability and replication (e.g., Pot1, TRF2, and helicases), and to follow the progression of replication forks at telomeres.

\section{Materials and Methods}

\subsection{Cell Culture and Cell Growth Experiments}

A549 cells were purchased from ATCC and cultured with Dulbecco's modified Eagle's medium (DMEM) with glutamax, supplemented with $10 \%$ fetal calf serum (FCS) and $1 \%$ penicillin/streptomycin. Cells were maintained in humidified incubators at $37^{\circ} \mathrm{C}$ in an atmosphere containing $5 \% \mathrm{CO}_{2}$ and ambient oxygen of $20 \%$. Cells were grown in $25 \mathrm{~cm}^{2}$ flasks (150,000 cells/ flask) and treated with $5 \mu \mathrm{M}$ of $360 \mathrm{~A}$ or $(360 \mathrm{~A})_{2 \mathrm{~A}}$ every 3 or 4 days (i.e., at each reseeding) until cultures were terminated. Control cells were either non-treated or treated with $0.1 \%$ DMSO. At each reseeding the remaining cells were pelleted and snap frozen for further DNA extraction.

\subsection{DNA Extraction and STELA}

DNA extraction was carried out with the ENZA tissue DNA kit for dry pellets of more than 100,000 cells and with the Qiagen QIAamp DNA mini kit (Les Ulis, France) for dry pellets of less than 100,000 cells. For $17 p$ telomere length analysis we used the modified STELA protocol previously described [5,8]. The genomic DNA was diluted at $30 \mathrm{ng} / \mu \mathrm{L}$ in $10 \mathrm{mM}$ Tris- $\mathrm{HCl}, \mathrm{pH}$. Then $120 \mathrm{ng}$ of DNA was further diluted in $40 \mu \mathrm{L}$ of $10 \mathrm{mM}$ Tris- $\mathrm{HCl}, \mathrm{pH}$ 8, containing $0.25 \mu \mathrm{M}$ Telorette 2. Multiple PCRs were carried out for each diluted DNA sample in a $10 \mu \mathrm{L}$ reaction mixture containing $3 \mathrm{ng}$ of diluted DNA, $0.5 \mu \mathrm{M}$ telomere adjacent (17p) and Teltail primers, $1 \mathrm{X}$ Taq Buffer and $0.5 \mathrm{U}$ of a 10:1 mixture of Taq (Thermo Fisher, Courtaboeuf, France), and Pwo polymerase (Roche, Meylan, France). The reactions were cycled with a BioRad C 1000 touch thermocycler (Marnes la Coquette, France) under the following conditions: 22 cycles of $94^{\circ} \mathrm{C}$ for $20 \mathrm{~s}, 59^{\circ} \mathrm{C}$ for $30 \mathrm{~s}$ and $68^{\circ} \mathrm{C}$ for $8 \mathrm{~min}$. The DNA fragments were resolved by $0.5 \%$ Tris-acetate-EDTA (TAE) agarose gel electrophoresis, and were detected by southern hybridization with a random-primed $\alpha{ }^{3}{ }^{33}$ P-labeled (Perkin Elmer, Villebon, France) telomere probe and a probe to detect the $1 \mathrm{~kb}$ (Stratagene, Les Ulis, France) and $2.5 \mathrm{~kb}$ (BioRad) molecular weight marker. The hybridized fragments were detected by phosphorimaging with a Thyphoon FLA 9500 (GE healthcare, Velizy, France). The molecular weights of the DNA fragments were calculated using Total Lab Quant (Newcastle, UK). 


\subsection{Oligonucleotides}

\section{7pseq1rev: 5'-GAATCCACGGATTGCTTTGTGTAC-3' \\ Teltail: $5^{\prime}$-TGCTCCGTGCATCTGGCATC-3' \\ Telorette 2: 5'-TGCTCCGTGCATCTGGCATCTAACCCT-3'}

\subsection{Chemical Compounds}

$360 \mathrm{~A}$ and $(360 \mathrm{~A})_{2 \mathrm{~A}}$ were synthesized as previously described [26]. Stock solutions were prepared in dimethyl sulfoxide (DMSO) at a concentration of $5 \mathrm{mM}$ and stored at $-20^{\circ} \mathrm{C}$.

\subsection{Statistical Analysis}

Statistical analysis was performed using GraphPad Prism 5. A Chi-square test was used to compare TDEs' frequencies.

Author Contributions: A.B. and L.R. conceived the project. I.H and L.R. performed the experiments, with the participation of V.H for cell growth. P.M. designed and synthesized the G4 ligands. L.R. supervised the study and analyzed the data. A.B. and L.R. interpreted the data and wrote the manuscript. J-F.R. substantively contributed to revision of the manuscript.

Funding: This work was supported by Inserm, CNRS (Centre National de la Recherche Scientifique), and the MNHN (Muséum National d'Histoire Naturelle).

Acknowledgments: We thank Pr. Chantal Trentesaux for initiating the cell growth experiments with the ligands and the members of the SANTE team for discussion.

Conflicts of Interest: The authors declare no conflict of interest.

\section{References}

1. Di Fagagna, F.D.A.; Reaper, P.M.; Clay-Farrace, L.; Fiegler, H.; Carr, P.; Von Zglinicki, T.; Saretzki, G.; Carter, N.P.; Jackson, S.P. A DNA damage checkpoint response in telomere-initiated senescence. Nature 2003, 426, 194-198. [CrossRef] [PubMed]

2. Palm, W.; de Lange, T. How shelterin protects mammalian telomeres. Annu. Rev. Genet. 2008, 42, 301-334. [CrossRef] [PubMed]

3. Olovnikov, A.M. A theory of marginotomy. The incomplete copying of template margin in enzymic synthesis of polynucleotides and biological significance of the phenomenon. J. Theor. Biol. 1973, 41, 181-190. [CrossRef]

4. Harley, C.B.; Futcher, A.B.; Greider, C.W. Telomeres shorten during ageing of human fibroblasts. Nature 1990, 345, 458-460. [CrossRef] [PubMed]

5. Baird, D.M.; Rowson, J.; Wynford-Thomas, D.; Kipling, D. Extensive allelic variation and ultrashort telomeres in senescent human cells. Nat. Genet. 2003, 33, 203-207. [CrossRef] [PubMed]

6. Baird, D.M.; Britt-Compton, B.; Rowson, J.; Amso, N.N.; Gregory, L.; Kipling, D. Telomere instability in the male germline. Hum. Mol. Genet. 2006, 15, 45-51. [CrossRef] [PubMed]

7. Britt-Compton, B.; Rowson, J.; Locke, M.; Mackenzie, I.; Kipling, D.; Baird, D.M. Structural stability and chromosome-specific telomere length is governed by cis-acting determinants in humans. Hum. Mol. Genet. 2006, 15, 725-733. [CrossRef]

8. Capper, R.; Britt-Compton, B.; Tankimanova, M.; Rowson, J.; Letsolo, B.; Man, S.; Haughton, M.; Baird, D.M. The nature of telomere fusion and a definition of the critical telomere length in human cells. Genes Dev. 2007, 21, 2495-2508. [CrossRef]

9. Bugaut, A.; Alberti, P. Understanding the stability of DNA G-quadruplex units in long human telomeric strands. Biochimie 2015, 113, 125-133. [CrossRef]

10. Granotier, C.; Pennarun, G.; Riou, L.; Hoffschir, F.; Gauthier, L.R.; De Cian, A.; Gomez, D.; Mandine, E.; Riou, J.F.; Mergny, J.L.; et al. Preferential binding of a G-quadruplex ligand to human chromosome ends. Nucleic Acids Res. 2005, 33, 4182-4190. [CrossRef]

11. Biffi, G.; Tannahill, D.; McCafferty, J.; Balasubramanian, S. Quantitative visualization of DNA G-quadruplex structures in human cells. Nat. Chem. 2013, 5, 182-186. [CrossRef] [PubMed] 
12. Paeschke, K.; McDonald, K.R.; Zakian, V.A. Telomeres: Structures in need of unwinding. FEBS Lett. 2010, 584, 3760-3772. [CrossRef] [PubMed]

13. Bochman, M.L.; Paeschke, K.; Zakian, V. A. DNA secondary structures: Stability and function of G-quadruplex structures. Nat. Rev. Genet. 2012, 13, 770-780. [CrossRef]

14. Hansel-Hertsch, R.; Beraldi, D.; Lensing, S.V.; Marsico, G.; Zyner, K.; Parry, A.; Di Antonio, M.; Pike, J.; Kimura, H.; Narita, M.; et al. G-quadruplex structures mark human regulatory chromatin. Nat. Genet. 2016, 48, 1267-1272. [CrossRef] [PubMed]

15. Hansel-Hertsch, R.; Di Antonio, M.; Balasubramanian, S. DNA G-quadruplexes in the human genome: Detection, functions and therapeutic potential. Nat. Rev. Mol. Cell Biol. 2017, 18, 279-284. [CrossRef] [PubMed]

16. Neidle, S. Human telomeric G-quadruplex: The current status of telomeric G-quadruplexes as therapeutic targets in human cancer. FEBS J. 2010, 277, 1118-1125. [CrossRef]

17. Neidle, S. Quadruplex Nucleic Acids as Novel Therapeutic Targets. J. Med. Chem. 2016, 59, 5987-6011. [CrossRef]

18. Islam, M.K.; Jackson, P.J.; Rahman, K.M.; Thurston, D.E. Recent advances in targeting the telomeric G-quadruplex DNA sequence with small molecules as a strategy for anticancer therapies. Future Med. Chem. 2016, 8, 1259-1290. [CrossRef]

19. Pennarun, G.; Granotier, C.; Gauthier, L.R.; Gomez, D.; Hoffschir, F.; Mandine, E.; Riou, J.F.; Mergny, J.L.; Mailliet, P.; Boussin, F.D. Apoptosis related to telomere instability and cell cycle alterations in human glioma cells treated by new highly selective G-quadruplex ligands. Oncogene 2005, 24, 2917-2928. [CrossRef]

20. Pennarun, G.; Granotier, C.; Hoffschir, F.; Mandine, E.; Biard, D.; Gauthier, L.R.; Boussin, F.D. Role of ATM in the telomere response to the G-quadruplex ligand 360A. Nucleic Acids Res. 2008, 36, 1741-1754. [CrossRef]

21. Gauthier, L.R.; Granotier, C.; Hoffschir, F.; Etienne, O.; Ayouaz, A.; Desmaze, C.; Mailliet, P.; Biard, D.S.; Boussin, F.D. Rad51 and DNA-PKcs are involved in the generation of specific telomere aberrations induced by the quadruplex ligand 360A that impair mitotic cell progression and lead to cell death. Cell. Mol. Life Sci. 2012, 69, 629-640. [CrossRef] [PubMed]

22. Gomez, D.; O’Donohue, M.F.; Wenner, T.; Douarre, C.; Macadre, J.; Koebel, P.; Giraud-Panis, M.J.; Kaplan, H.; Kolkes, A.; Shin-ya, K.; et al. The G-quadruplex ligand telomestatin inhibits POT1 binding to telomeric sequences in vitro and induces GFP-POT1 dissociation from telomeres in human cells. Cancer Res. 2006, 66, 6908-6912. [CrossRef] [PubMed]

23. Tahara, H.; Shin-Ya, K.; Seimiya, H.; Yamada, H.; Tsuruo, T.; Ide, T. G-Quadruplex stabilization by telomestatin induces TRF2 protein dissociation from telomeres and anaphase bridge formation accompanied by loss of the 3' telomeric overhang in cancer cells. Oncogene 2006, 25, 1955-1966. [CrossRef] [PubMed]

24. Hampel, S.M.; Pepe, A.; Greulich-Bode, K.M.; Malhotra, S.V.; Reszka, A.P.; Veith, S.; Boukamp, P.; Neidle, S. Mechanism of the antiproliferative activity of some naphthalene diimide G-quadruplex ligands. Mol. Pharmacol. 2013, 83, 470-480. [CrossRef]

25. Rizzo, A.; Salvati, E.; Porru, M.; D’Angelo, C.; Stevens, M.F.; D’Incalci, M.; Leonetti, C.; Gilson, E.; Zupi, G.; Biroccio, A. Stabilization of quadruplex DNA perturbs telomere replication leading to the activation of an ATR-dependent ATM signaling pathway. Nucleic Acids Res. 2009, 37, 5353-5364. [CrossRef] [PubMed]

26. Saintome, C.; Alberti, P.; Guinot, N.; Lejault, P.; Chatain, J.; Mailliet, P.; Riou, J.F.; Bugaut, A. Binding properties of mono- and dimeric pyridine dicarboxamide ligands to human telomeric higher-order G-quadruplex structures. Chem. Commun. 2018, 54, 1897-1900. [CrossRef]

27. Sfeir, A.J.; Chai, W.; Shay, J.W.; Wright, W.E. Telomere-end processing the terminal nucleotides of human chromosomes. Mol. Cell 2005, 18, 131-138. [CrossRef]

28. Sidibe, A.; Hamon, F.; Largy, E.; Gomez, D.; Teulade-Fichou, M.P.; Trentesaux, C.; Riou, J.F. Effects of a halogenated G-quadruplex ligand from the pyridine dicarboxamide series on the terminal sequence of XpYp telomere in HT1080 cells. Biochimie 2012, 94, 2559-2568. [CrossRef]

29. Baird, D.M. New developments in telomere length analysis. Exp. Gerontol. 2005, 40, 363-368. [CrossRef]

30. Mendoza, O.; Bourdoncle, A.; Boule, J.B.; Brosh, R.M., Jr.; Mergny, J.L. G-quadruplexes and helicases. Nucleic Acids Res. 2016, 44, 1989-2006. [CrossRef]

31. Crabbe, L.; Verdun, R.E.; Haggblom, C.I.; Karlseder, J. Defective telomere lagging strand synthesis in cells lacking WRN helicase activity. Science 2004, 306, 1951-1953. [CrossRef] [PubMed] 
32. Wold, M.S. Replication protein A: A heterotrimeric, single-stranded DNA-binding protein required for eukaryotic DNA metabolism. Annu. Rev. Biochem. 1997, 66, 61-92. [CrossRef] [PubMed]

33. Verdun, R.E.; Karlseder, J. The DNA damage machinery and homologous recombination pathway act consecutively to protect human telomeres. Cell 2006, 127, 709-720. [CrossRef] [PubMed]

34. Dejardin, J.; Kingston, R.E. Purification of proteins associated with specific genomic Loci. Cell 2009, 136, 175-186. [CrossRef] [PubMed]

35. Kobayashi, Y.; Sato, K.; Kibe, T.; Seimiya, H.; Nakamura, A.; Yukawa, M.; Tsuchiya, E.; Ueno, M. Expression of mutant RPA in human cancer cells causes telomere shortening. Biosci. Biotechnol. Biochem. 2010, 74, 382-385. [CrossRef] [PubMed]

Sample Availability: Samples of the compounds are available from the authors.

(C) 2019 by the authors. Licensee MDPI, Basel, Switzerland. This article is an open access article distributed under the terms and conditions of the Creative Commons Attribution (CC BY) license (http:/ / creativecommons.org/licenses/by/4.0/). 